\title{
Teachers as brokers: adding a university-society perspective to higher education teacher competence profiles
}

\author{
Carla Oonk, et al. [full author details at the end of the article]
}

Published online: 2 April 2020

(C) The Author(s) 2020

\begin{abstract}
Higher education institutions are increasingly engaged with society but contemporary higher education teacher competence profiles do not include university-society oriented responsibilities of teachers. Consequently, comprehensive insights in university-society collaborative performance of higher education teachers are not available. This study empirically develops a teacher profile for an exemplary university-society oriented, multi-stakeholder learning environment and builds an argument for university-society collaborative additions to existing higher education teacher profiles. A showcase example of a new university-society collaborative, multi-stakeholder learning environment, the Regional Learning Environment (RLE), provides the context of analysis. Thirteen RLE establishments were included in the study. The study uses a descriptive qualitative design, triangulating data from RLE documents, teacher interviews and focus groups with teachers and managers on RLE teacher roles, tasks and competencies. The resulting RLE teacher profile comprises nine roles, nineteen tasks and 21 competencies. The new profile echoes scattered indications for teacher responsibilities as identified in previous studies on teaching and learning in university-society collaborative learning settings. The study argues that the role of broker, including boundary crossing competence, and the competency 'stimulating a collaborative learning attitude', might be added to existing higher education teacher competence profiles. Adding this university-society engaged perspective to existing teacher competence profiles will support higher education institutions in developing their university-society collaborative responsibilities and subsequent teacher professionalisation trajectories.
\end{abstract}

Keywords Boundary crossing competence $\cdot$ Higher education · University-society engagement . Teacher competence profile

Electronic supplementary material The online version of this article (https://doi.org/10.1007/s10734-02000510-9) contains supplementary material, which is available to authorized users. 


\section{Introduction}

Nowadays, higher education institutions are expected to be relevant to and engaged with society (OECD-IMHE 2012; European Union 2013). Society benefits from knowledge produced in academia, whereas higher education students and staff benefit from working on reallife projects to acquire professional skills and enrich their practical experience (Jacoby 2014; Scholz and Steiner 2015; Watson et al. 2011). However, collaboration and mutual learning between higher education institutions and society are demanding for institutional governance (Jongbloed et al. 2008), as well as for stakeholders, students and academic staff involved (e.g. Coates and Goedegebuure 2012; Webb and Burgin 2009; Yarime et al. 2012). The doors of universities, representing a boundary between the relatively safe and autonomous academic institutional world, and the complex, multi-stakeholder society, literally have to be opened. For academic staff, this means that, in addition to their regular tasks, they need to develop the willingness and ability to create and foster university-society partnerships, contribute to research agendas, develop real-life learning activities for students and start to collaborate with external stakeholders, while guiding the students through multi-stakeholder research processes and supporting relevant student competencies.

Since the last decade of the 20th century, the mutual benefits of university-society partnerships and the design of authentic learning environments in which students and academic staff collaborate with external partners have received increasing attention in educational research and scholarly debates (e.g. Oonk et al. 2016, 2017; Guzmán-Valenzuela 2015; Jacoby 2014; Yarime et al. 2012). However, studies contributing to this debate only pay implicit attention to what is required from university teachers to perform in university-society collaborative practices (Brundiers et al. 2013; Stauffacher et al. 2006). Until today, a systematic identification of the roles and tasks that teachers fulfil in university-society collaborative learning environments, and the competencies that teachers should master to carry out these tasks, has not been accomplished. Moreover, generic higher education teacher competence profiles typically focus on traditional in-class roles and/or competencies of teachers (e.g. Gilis et al. 2008; Tigelaar et al. 2004; VSNU-NOA 2016), such as the expert on content knowledge and being able to set up and guide student learning processes in consultation with other teacher colleagues. These profiles only marginally address university-society-oriented elements. They occasionally briefly refer to external, one-to-one relations of teachers with for example workplace supervisors, guest speakers or inspection officers.

If universities want to meet the demand of society engagement, teachers should be better prepared for university-society collaborative practices (Whitmer et al. 2010). To achieve this, a comprehensive understanding of responsibilities and requirements for teacher performance in a university-society-engaged setting is needed. The present study aims to provide this understanding by systematically analysing teachers' roles, tasks and competencies within one exemplary learning environment: the authentic, multi-stakeholder Regional Learning Environment (RLE), and develop a comprehensive RLE teacher profile. The RLE is an example of a university-society collaborative learning environment comparable with studios and servicelearning environments (Oonk et al. 2016, 2017; Foorthuis et al. 2012). In the RLE, multiple societal stakeholders, academic staff and students co-create new knowledge aiming at enhancing sustainable regional innovation. The RLE requires teachers to perform within an intensive university-society collaborative experience. As such, the RLE provides a proper exemplary context for studying university-society collaborative roles, tasks and competencies of higher education teachers. 
This study empirically deduces a comprehensive teacher profile for teacher performance in a university-society collaborative learning environment by examining the research question of 'Which roles, tasks and competencies do teachers fulfil in the RLE and how are these associated?'. In the next section, we will first describe the educational design of the RLE which is needed to understand teacher responsibilities in a university-society collaborative learning environment. The second section discusses indications for new teacher tasks and capabilities as provided in earlier studies on working and learning in various university-society learning settings, other than the RLE. These studies never had the objective to systematically investigate new teacher requirements. But, the fact that new requirements are often illuminated in the sidelines of these studies confirms the need for more attention to new teacher requirements, for which an empirically developed comprehensive overview is supposed to be a useful start.

After the presentation of the methods and our resulting RLE teacher profile, we thoroughly review the resulting profile in the 'Discussion' section by addressing its recognisability, added value and limitations, and arguing which university-society collaborative teacher roles and competencies should be added to existing higher education teacher competence profiles in order to support respective professionalisation and performance of teachers.

\section{The Regional Learning Environment as an exemplary university-society learning environment}

The RLE is a real-world, long-term, multi-stakeholder learning environment in which stakeholders from government, businesses, NGOs, research and education learn and co-create new knowledge aiming at stimulating sustainable regional innovation (Oonk et al. 2016, 2017; Foorthuis et al. 2012; Meijles and Van Hoven 2010). Stakeholders cooperate in various projects in different team constellations. One example of an RLE is the RLE Peat District (Kenniswerkplaats Veenkoloniën) (Meijles and Van Hoven 2010). In this RLE, local and regional governmental bodies, entrepreneurs, NGO's and educational institutions collaboratively developed and adopted a long-term innovation agenda for tackling issues related to climate change, biodiversity loss and economic and social decline.

From an educational design perspective, the RLE provides an authentic (e.g. De Kock et al. 2004; Herrington and Oliver 2000), multi-stakeholder learning environment for students as well as for teachers from multiple educational programmes simultaneously. The RLE shares many characteristics with other well-known university-society learning environments such as service learning, in which students learn by providing service to communities, and the studio, in which students get through a design process often based on authentic assignments (Oonk et al. 2016, 2017; Brandt et al. 2013; Jacoby 2014). Specific RLE design characteristics include the following. First, students and their teachers work on complex, transdisciplinary regional problems in a real-life context that require collaboration with multiple stakeholders including their diverse perspectives and interests (Scholz and Steiner 2015). Second, these problems, translated into project assignments, are always commissioned by an external client from the region. Third, students work on the assignments in student groups, preferably multidisciplinary student groups including students from different educational programmes. Fourth, RLE work results in various types of realistic products that have value for the external client(s) and, ideally, contribute to regional development. Finally, all parties involved, i.e. students, teachers and other stakeholders, are co-participants and expected to learn and collaboratively create new knowledge. 
Teachers can potentially be involved in all steps of the RLE working process (Foorthuis et al. 2012). This working process includes (1) the development of a joint regional innovation agenda, and the mobilisation of relevant stakeholders, (2) translation of the more abstract research themes into feasible projects and the organisation of respective learning activities, (3) formalisation of mutual learning expectations of all stakeholders into so-called learning contracts, (4) project execution, and (5) dissemination, and optimisation and continuation of the partnership. Tasks of teachers include initiating regional networks, organizing learning activities, coaching students in their collaboration with multiple external stakeholders and facilitating other RLE co-participants' collaborative processes. This implies that teachers fulfil different and over time varying roles and tasks for which they need to master several competencies. Of course, at the same time, teachers retain their original responsibilities such as supervising students, and assessing their learning results, though these duties might also get different meanings in the RLE context. As such, working as a teacher in the RLE requires new, university-society-oriented responsibilities in addition to perform previously established roles for supporting students' in-class learning processes. Indications for these new responsibilities can also be traced in previous studies on working and learning in various university-society settings.

\section{Indications for teacher requirements in university-society learning settings}

The creation of a comprehensive university-society collaborative teacher profile was never the main objective of studies on university-society learning settings (Brundiers et al. 2013). However, recent educational studies on building university-society partnerships and the design of university-society collaborative learning environments in higher education appear to often illuminate, as by-products of the studies, various new teacher requirements for working in university-society learning settings.

To start working in a university-society setting, partnerships with public and/or private organisations need to be built (Jongbloed et al. 2008; Lansu et al. 2013). Teachers are expected to build and maintain networks (Ruskovaara et al. 2015), and create and manage collaborative projects (Brundiers et al. 2013), including the creation of opportunities for student participation (Rosenberg Daneri et al. 2015). For this to occur, a teacher is supposed to have a basic understanding of out-of-university, real-world topics at stake, to be visionary and entrepreneurial, and to master adaptive communication and negotiation skills (Brundiers et al. 2013). The teacher should also possess project management skills like being well-organized, and being able to manage resources, and monitor and evaluate project processes (Brundiers and Wiek 2011; Brundiers et al. 2013; Forsyth et al. 1999; Jacoby 2014).

Next, multi-stakeholder collaborative processes, as running in the partnerships, need to be facilitated. This task appears to be taken up, amongst others, by academic staff (e.g. Brundiers et al. 2013; Stauffacher et al. 2006). A facilitator enables and catalyses a continuous collaborative process amongst different communities, including students, in order to coach participants in conducting participatory research, co-produce knowledge and stimulate social learning (Meijles and Van Hoven 2010; Trencher et al. 2013; Wals et al. 2009). A facilitator is approachable, empathic and open, and masters sensibility, mediation and conflict-resolution skills (Brundiers and Wiek 2011; Klein et al. 2011).

Trencher et al. (2013) also describe the use of knowledge expertise of teachers in real-life university-society partnerships. Teachers create, demonstrate and diffuse cutting-edge innovative ideas, and influence developmental and governing trajectories by advising appropriate 
implementation strategies. Forsyth et al. (1999) highlight the time-consuming responsibility of expert teachers in the service-learning studio for double-checking and finishing up loose ends of final student products before presenting them to the community. Making scientific knowledge understandable for non-experts and inciting community knowledge ownership by joint knowledge creation are considered two important capabilities for the university-societyengaged teacher (Peer and Stoeglehner 2013; Trencher et al. 2013).

Studies on the educational design of university-society learning arrangements stress teacher responsibilities in translating community demands into educational assignments and the curriculum (Rosenberg Daneri et al. 2015). The teacher is regarded to set objectives for student and community learning simultaneously, and to develop real-life learning activities including practice-based assessments that provide opportunities for student input in stakeholder collaborations. The translation responsibilities also include to implement these learning activities into the curriculum, while adapting to common misalignment between community and educational timelines (Jacoby 2014; Rosenberg Daneri et al. 2015).

Compared with in-class coaching, coaching student-community collaborative projects in university-society learning environments also includes new responsibilities (Stauffacher et al. 2006). Students should be stimulated to acquire participatory competence. This means students should be supported in how to for example translate scientific knowledge into community engagement, increase societal engagement and respond to unpredictable process dynamics that university-society collaborations encounter (e.g. Webb and Burgin 2009). Teachers' tasks comprise of organising and guiding consequential dynamic learning processes (Sletto 2010) in which teachers act amidst students and stakeholders, including their expectations and perspectives. Teachers are expected to coach students in a participatory manner on internal and external collaboration, offer a programme of supportive workshops on different collaborative issues (Vilsmaier and Lang 2015) and ensure students' critical reflection (Sletto 2010; Stauffacher et al. 2006). Summarized, crucial for coaching students in university-society learning settings is the ability to facilitate student group processes together with a full understanding of multistakeholder working and learning processes (Rosenberg Daneri et al. 2015; Stauffacher et al. 2006). Studies on service learning highlight the crucial essence of critical reflection in student learning from working with community partners, and the subsequent role and capabilities of the student project coach as a facilitator of reflection (Giles Jr and Eyler 1994; Jacoby 2014; Sletto 2010). Facilitating reflection comprises guiding students through the ongoing process of (re)considering their values, beliefs and acquired knowledge. This would enable them to question their a priori assumptions, recognize complexity and reconsider how their practices relate to others' practices (Jacoby 2014). Regarded key in mastering the facilitation of reflection is the ability to organise reflection (when, where, whom involved?), to ask the right questions at the right moment, to show respect for viewpoints, to balance challenge and support and to openly discuss subjectivity (Jacoby 2014; Sletto 2010).

Last, showing a learning attitude is seen as crucial in transdisciplinary research and education, obviously more explicit than in education in general (e.g. Forsyth et al. 1999; Klein et al. 2011; Lang et al. 2012; Lansu et al. 2013; Stauffacher et al. 2006). Teachers are expected to be open to learning, to actively reconsider own practices as a result of the learning and to contribute to mutual learning processes between all participants involved.

The above indications for new requirements justify the need for our study: teachers in university-society settings are exposed to new challenges. A comprehensive overview of 
what is expected from teachers is not yet available. Our study aims at systematically and empirically identifying roles, tasks and competencies in order to provide one full profile for teacher performance in an exemplary university-society collaborative learning environment.

\section{Method}

The empirical part of this study was carried out in a qualitative, descriptive design. Teachers' roles, tasks and competencies in the RLE were identified through a document analysis complemented with the analysis of teacher interview and focus group discussion data. All data were analysed in a multi-rater, iterative, in vivo coding process (Miles et al. 2014).

\section{Procedure for developing the RLE teacher profile}

To be able to develop a comprehensive teacher profile for the RLE, an appropriate understanding of all responsibilities and requirements for teachers in the RLE is needed. Using working processes in the working context, including responsibilities and requirements of employees in these processes, is regarded an effective approach for creating a job competence profile (Dubois 1993; Mulder et al. 2005; Wesselink 2010). This approach involves the structuring of a profession (in this study the teacher), based on working processes in a certain context (in this study, the RLE) into main roles, associated tasks and competencies that need to be mastered to perform a certain role and/or set of tasks (Mulder 2014, 125). A quick scan of the collected data for this study revealed clear roles, tasks and competency descriptions to occur. A role was defined as a label for a meaningful cluster of tasks, and helpful in structuring tasks as found in the data. A task was defined as an activity that was carried out, or supposed to be carried out, by a teacher executing a step in the working process of the RLE (see section 'The Regional Learning Environment as an exemplary university-society learning environment'). A competency was defined as an integrated cluster of knowledge, skills, attitudes and/ or personal traits enabling a person to perform a certain task or a set of tasks associated to a role (Mulder 2014; Mulder 2017). The three constructs of role, task and competency were used as basic coding categories of the constructed coding frame. The respective codes unfolded while coding the data in vivo.

A document analysis on practical working documents (see next section 'Document analysis') resulted in a draft profile. By mirroring the draft profile with teacher data from interviews and focus groups, we created an empirically underpinned RLE teacher profile.

\section{Document analysis}

Lacking any scientific sources on the new RLE, we opted for a document analysis on 95 selected practical documents that included expressions on teacher performance in the RLE. The website www.dewerkplaats.eu (later transferred into www.groenkennisnet.nl [green knowledge_net]) was used as a basic source for the selection of the documents. This website was the main official communication medium for all 13 Dutch RLEs. All RLE practitioners used this website to upload their complete range of publicly shared documents. We included in our selection all complete documents that contained one or more expressions from teachers, and other involved practitioners talking about teachers, on their duties and 
abilities until the date of the analyses for this study (end of 2011). The final selection included 95 documents different in type: business plans, information brochures and films, annual reports and evaluation reports.

From all documents, each meaningful expression from a teacher or from another RLE practitioner referring to a teacher role, task or ability was extracted and described as a single excerpt. This resulted in a document of 677 meaningful excerpts. Each excerpt was first categorised by the first author as a role, task, competency or a combination of these.

All excerpts categorised as role were openly coded by the first author by assigning role labels to them (Strauss 1987, p. 58). Each excerpt containing a new role description was attributed a new role label. All excerpts categorised as task were coded in the same way. In each case, the excerpt provided a link between a task and a role; the task was associated with a role (e.g. 'the student project coach [i.e. a role] should support students in finding the right persons and organisations' [i.e. a task]). In case, this link was not provided in the data (e.g. 'you should monitor the quality standard for the project as set at the start'); the task was put in a box 'non-role-associated tasks'. All excerpts categorised as competency were first coded in the same open way, after which one aggregating step was built in by combining detailed descriptions of competencies into more generally defined competencies (e.g. 'listening well to all people involved' and 'being able to give other people room to express themselves' were labelled 'social skills to communicate with different stakeholders'). This was done to prevent for a long list of detailed competencies but construct a list of clear, distinctive competencies. In each case that the excerpt provided a conditional link between a competency, and a role and/or task, the competency was regarded useful for the performance of, and associated with, that role and/or task (e.g. 'the business developer should have insight in regional organisational structures'). In case links between competencies and roles and/or tasks were not provided in the data, the competencies were put in the box 'non-associated competence domains'.

To increase the reliability of the coding work, two co-authors openly coded a randomly selected $10 \%$ of the role and task excerpts (Cohens' $\kappa=0.82$ ), and coded for the full competency aggregating step $(\kappa=0.72)$. These two inter-rater reliability scores represented an almost perfect respectively substantial strength of agreement (Landis and Koch 1977). The three raters together discussed differences until they reached consensus. The document analysis resulted in a draft RLE teacher profile.

\section{Interviews and focus group discussions}

To validate the draft teacher profile, the first author of the paper conducted six interviews with active RLE teachers ( $n=6$ ) working in 5 different RLEs and 13 focus group discussions with RLE teachers and school managers $(n=78)$ in mixed groups from all 13 RLEs. The interviewees were asked two open questions, i.e. 'which roles and tasks should the RLE teacher perform in the RLE?', and 'which competencies should be mastered to execute these tasks?'. Each interview took 45-60 min. The focus group discussions used the World Café method (Brown and Isaacs 2005). All participants took part in three successive discussion rounds of 20 min each. In each round, they sat with averagely five table mates at a table of their choice. They switched tables each round. At each table, they built up a discussion on experienced and expected roles, tasks and competencies of RLE teachers. During the discussions, all participants recorded findings of their table discussions on table cloths that were visible for all table mates. Findings could, during the three discussion rounds, be adjusted and completed by all table mates which enabled validation. 
Transcribing all interview recordings and focus group discussion reports into meaningful excerpts resulted in 422 excerpts. These excerpts were categorised and coded in the same way as the excerpts from the documents. In case a coded role, task or competency was similar to one found through the document analysis, it was regarded as to verify the draft profile and then further neglected. In case a coded role, task or competency appeared to be an addition to the draft profile, it was added to the draft profile and marked as an addition. As such, the interview and focus group data were only used to add to the draft profile. The elements identified through the thorough document analysis were kept intact despite they did not reveal from the interview and focus group data.

\section{Results}

The main research question of this study was 'Which roles, tasks and competencies do teachers fulfil in the RLE, and how are these associated?' The document analysis first resulted in a draft RLE teacher profile including eight roles, one to four tasks per role and 21 competencies, all associated to one or more roles. The analysis of the interview and focus group data then resulted in one additional role and associated task, and an additional task for one already identified role. No additional competencies were found. The draft RLE teacher profile was complemented with the additional role and tasks from the interviews and focus group discussions, which resulted in our main finding: a teacher profile for working as a higher education teacher in the multi-stakeholder university-society RLE (see Table 1 for roles and tasks and Appendix 1 for competencies).

Taking a closer look into the RLE teacher profile, we identify at least four out of nine roles as to be specifically university-society oriented, and new to existing in-school-oriented profiles based on their associated identified task lists (Gilis et al. 2008; Tigelaar et al. 2004; see Table 1, bold roles). The task lists of the new roles business developer, learning project developer, process facilitator and co-participant predominantly comprise responsibilities for which university-society relationships and collaborative activities are crucial. Illustrative examples of these tasks are building multi-stakeholder networks and knowledge agendas, translating real-world assignments into feasible student projects, and facilitating transdisciplinary learning trajectories. The expert is already known from in-school-oriented profiles (Tigelaar et al. 2004) and therefore not indicated a new role. However, on the basis of our results, the expert should indeed be indicated as the fifth university-society collaborative role considering the newly identified responsibilities of matching the quality of student project outcomes with the expectations of real-life partners and caring for a wider, out-of-university, distribution of cocreated knowledge and methods. The role of learner in a learning network has also been identified before (Tigelaar et al. 2004; VSNU-NOA 2016). However, the RLE task description for the learners' task stresses its collaborative manifestation related to learning from the collaboration with multiple external stakeholders in the RLE. The student project coach is a well-known academic role, although the identified task element of working with students from various disciplines and educational levels in one project is new to existing profiles. The assessor and curriculum innovator are also existing academic roles, although the identified RLE tasks for these roles comprise the new aspect of balancing between in- and out-ofacademia demands in terms of assessment and, e.g. programming and scheduling. Respecting existing teacher profiles, we cannot indicate the roles of expert, learner, student project coach, assessor and curriculum innovator as to be new roles. However, these roles all include new 
Table 1 Roles and tasks of higher education teachers in the Regional Learning Environment (Italic: added as a result from the interview and focusgroup data analysis; bold: new to existing teacher competence profiles)

\begin{tabular}{|c|c|}
\hline Role & Tasks \\
\hline 1. Business Developer & $\begin{array}{l}\text { a. To initiate, build and maintain strategic networks in the region } \\
\text { b. To contribute to the preparation of the regional knowledge agenda } \\
\text { c. Acquisition of project assignments in which students can participate } \\
\text { d. Organization of the RLE working process }\end{array}$ \\
\hline $\begin{array}{l}\text { 2. Learning Project } \\
\text { Developer }\end{array}$ & $\begin{array}{l}\text { a. Translation of a regional demand (mostly an item from the regional knowledge } \\
\text { agenda) into one or more feasible project assignments for various educational } \\
\text { programmes } \\
\text { b. Planning and organization of student projects (i.e. scheduling, staffing and } \\
\text { financing) } \\
\text { c. Supporting students and stakeholders in the articulation of real-world project } \\
\text { assignments }\end{array}$ \\
\hline 3. Process Facilitator & $\begin{array}{l}\text { a. Management of expectations with respect to involved clients, educational } \\
\text { institutions and students } \\
\text { b. Facilitating mutual learning in a transdisciplinary learning network with project } \\
\text { members from different disciplines and educational levels } \\
\text { c. Facilitating reflexive monitoring in a transdisciplinary network } \\
\text { d. Controlling the commonly set working agreements and quality standards }\end{array}$ \\
\hline $\begin{array}{l}\text { 4. Student Project } \\
\text { Coach }\end{array}$ & $\begin{array}{l}\text { a. Supervision of student projects in terms of a content oriented, methodological } \\
\text { and process-oriented guidance of student project teams often consisting of } \\
\text { students from various disciplines and educational levels }\end{array}$ \\
\hline 5. Assessor & $\begin{array}{l}\text { a. Assessment of a student project in the light of both the educational requirements } \\
\text { and the requirements of the client }\end{array}$ \\
\hline 6. Co-participant & a. To participate in projects as an equal partner in relation to other co-participants \\
\hline 7. Expert & $\begin{array}{l}\text { a. To develop and distribute co-created knowledge and research methods } \\
\text { b. To upgrade or translate project results of students into a useful product for the } \\
\text { client }\end{array}$ \\
\hline $\begin{array}{l}\text { 8. Curriculum } \\
\text { Innovator }\end{array}$ & $\begin{array}{l}\text { a. Transfer of (in RLE projects) co-created new knowledge into other curricular } \\
\text { courses } \\
\text { b. Structural embedding of the RLE into the curriculum and into the institutional } \\
\text { organization }\end{array}$ \\
\hline $\begin{array}{l}\text { 9. Learner in a learning } \\
\text { network }\end{array}$ & a. To be an active and collaborative learner \\
\hline
\end{tabular}

tasks and require new competencies since teachers fulfil them in a new, university-society context.

Our identified competence list (see Appendix 1) reflects that all nine RLE roles, both new and existing, require various new capabilities of teachers compared with their inside academia capabilities. Nineteen out of 21 RLE competencies are associated in the data with (i.e. are regarded as to be relevant to) both new and existing roles. Only two competencies, namely 'being able to assess student learning outcomes' and 'to translate RLE learning experiences into new learning activities', are only associated in the data with existing teacher roles. Table 2 shows the nine out of 21 identified RLE competencies that are associated in the data with the majority of the identified roles; in other words, Table 2 shows the nine most relevant competencies for performing the identified RLE roles.

The majority of these most relevant competencies (see Table 2) explicitly refer to teachers' ability to collaborate with external stakeholders in a multi-stakeholder setting. This ability includes understanding of the social system, skills to connect to external networks and maintain them, and a pioneering attitude which involves thinking beyond the own frame of reference and daring to take risks. 
Table 2 Identified RLE competencies as associated with the majority of the RLE roles, and respective RLE roles as associated with

Competency

Capabilities to act effectively within the complex and dynamic system of a transdisciplinary learning environment in which complex societal issues are faced

Knowledge of the relevant social system, in casu relevant external stakeholders and their practices

Social skills to communicate with different external stakeholders

Being able to connect various stakeholders

Being able to continuously switch between and serve educational and stakeholders' interests

Being able to monitor the quality standard as set in consultation with the stakeholders and increase the quality of products to be delivered

Leadership in both in- and out-of-university working processes
RLE Roles associated with

Business developer

Learning project developer

Process facilitator

Student project coach

Assessor

Co-participant

Expert

Curriculum innovator

Learner in a learning network

Generally mentioned, non-associated to a role

Business developer

Learning project developer

Process facilitator

Co-participant

Generally mentioned, non-associated to a role

Business developer

Learning project developer

Process facilitator

Co-participant

Expert

Learner in a learning network

Business developer

Learning project developer

Process facilitator

Co-participant

Expert

Curriculum innovator

Learner in a learning network

Generally mentioned, non-associated to a role

Process facilitator

Student project coach

Co-participant

Expert

Curriculum innovator

Substantive understanding of real-life project topics and RLE project proposals Business developer

Learning project developer

Process facilitator

Co-participant

Expert

Generally mentioned, non-associated to a role

Process facilitator

Student project coach

Assessor

Expert

Curriculum innovator

Business developer

Learning project developer

Process facilitator

Curriculum innovator

Learner in a learning network 
Table 2 (continued)

\begin{tabular}{ll} 
Competency & RLE Roles associated with \\
\hline & $\begin{array}{l}\text { Generally mentioned, } \\
\text { non-associated to a role } \\
\text { Process facilitator }\end{array}$ \\
& $\begin{array}{l}\text { Student project coach } \\
\text { Co-participant }\end{array}$ \\
& Expert \\
Learner in a learning network
\end{tabular}

\section{Discussion}

This 'Discussion' section reviews in several ways the developed RLE teacher profile, i.e. the result of this study, and considers its further use. First, we will evaluate the recognisability of the developed profile by comparing the profile with the indications for new teacher requirements as sparsely indicated in previous studies on working and learning in university-society settings. Second, the added value of the profile will be substantiated by showing how the profile adds to existing higher education teacher profiles. Based on this review of the RLE profile, we allow ourselves to build an argument for providing additions to existing teacher profiles in order to make them university-society proof. The 'Discussion' section ends with limitations of the study, practical implications and suggestions for future studies.

\section{Recognising previous indications for new teacher requirements in the RLE profile}

The resulting RLE teacher profile offers a comprehensive overview of teacher requirements for university-society learning settings: while it covers teachers' working in the RLE, it also reflects indications for teacher requirements from other university-society settings. As such, the RLE profile systematically combines and categorises many scattered components into one clear overview of roles, tasks and competencies.

Organisational and managerial tasks and competencies required for building and maintaining networks and partnerships (Brundiers et al. 2013; Lansu et al. 2013; Ruskovaara et al. 2015) are reflected in the RLE business developer.

The RLE learning project developer is responsible for translating real-life demands into feasible student projects as similarly mentioned by Rosenberg Daneri et al. (2015). Rosenberg Daneri et al. (2015) and Jacoby (2014) also notice new responsibilities and capabilities where it comes to the implementation of university-society learning environments and activities into the curriculum. The RLE assigns the responsibilities at the curricular level to the role of the curriculum innovator.

The RLE process facilitator covers the previously mentioned responsibilities for expectation management and stimulating mutual learning (Meijles and Van Hoven 2010; Trencher et al. 2013; Wals et al. 2009). The task to facilitate reflexive monitoring in a transdisciplinary network has not been described as such in previous studies, while identified as a new task for the RLE process facilitator. Organising reflection amongst students seems to just receive much more attention in other university-society learning settings compared with the RLE (Jacoby 2014; Sletto 2010).

The RLE expert role combines the previously found teacher requirements of developing and distributing co-created knowledge and methods as well as upgrading student results into a 
useful product for the client (Forsyth et al. 1999; Peer and Stoeglehner 2013). Contrary, the knowledge expert as described by Trencher et al. (2013) is categorised under the co-participant role in the RLE profile as its main focus was on using content expertise in university-society settings as a co-participant in real-life projects.

Frankly, being a learner, by openly showing a learning attitude and stimulate other participants' learning, has been described as being crucial to society-engaged performance by many scholars (e.g. Lansu et al. 2013; Stauffacher et al. 2006).

The RLE roles and tasks of student project coach and assessor leave us with some open endings. We did not find explicit assessment responsibilities in previous studies, although our study resulted in distinguishing a separate role for the assessor. On the other hand, coaching students' learning and reflection gained more attention in other university-society settings, especially in service learning (Jacoby 2014; Sletto 2010). Remarkably, two previous studies on student learning in the RLE just highlighted a high coaching intensity to be a precondition for student learning in the RLE (Oonk et al. 2016, 2017). Little attention for student-coaching and much attention for assessment in our present study might be due to the by then developmental stage of the RLE. Setting up the RLE including collaborations with external partners seems to require a lot from the teachers at the macro and meso level (Foorthuis et al. 2012), inciting roles like business developer and learning project developer, before being ready for the micro level that encompasses project-executing and student-coaching tasks. Next, the inspectorate of education stressed the importance of sound assessment criteria and instruments for this innovative RLE. This may have incited a relatively high level of attention for assessment in the RLE. Repeating the study on more recent documents and interview data, that are expected to reflect a more established status of the RLE, may reveal more teacher-student-coaching tasks and less attention for assessment.

We allow ourselves to conclude that the RLE profile offers a comprehensive overview of requirements for teachers working in university-society settings that reflects, combines and categorises scattered indications for teacher requirements as found in previous studies on university-society learning settings. This strengthens the added value of this study in empirically proving and systematically presenting what is required from teachers in universitysociety settings.

\section{Added value of the RLE teacher profile in comparison with existing generic teacher profiles}

Higher education worldwide does not have a tradition of using generic quantitative evaluation standards for the quality of teaching. Instead, every institution is responsible for its own teaching quality and should set the bar internally (OECD-IMHE 2012). There is, however, much policy debate on what high-quality teaching involves (OECD-IMHE 2012; European Union 2013), which leads to increasing country-specific attempts to translate these debates into guiding competency frameworks for higher education teachers. Policy debates also prompted scientific research on teacher roles, tasks and competencies for various educational approaches and settings (Barnett and GuzmánValenzuela 2017; Coates and Goedegebuure 2012; Kyvik 2013). Resulting teacher profiles and/or competence frameworks are expected to enhance the quality of education and support educational institutions to adapt to a certain educational approach or innovation (Wesselink 2010; Tigelaar et al. 2004). The profiles are used to inform teacher professionalisation and evaluation trajectories (Mulder 2017). 
In order to effectively contribute to professionalisation, the teacher profiles should reflect up-to-date teacher working contexts and responsibilities. However, existing profiles appear to show gaps where it comes to cover the university-society collaborative settings in which many teachers work or come to work. To support this claim, we reviewed a selection of actual generic policy and scientific teacher profiles on roles, tasks and/or competencies that explicitly refer to university-society-oriented aspects of higher education teachers' work (Wesselink 2010; Gilis et al. 2008; Onderwijscoöperatie 2014; Smith and Simpson 1995; Tigelaar et al. 2004; VSNU-NOA 2016). The majority of the existing profiles only refer in 4-6\% of their included items to university-society-oriented duties and/or capabilities. Moreover, in case the requirements do explicitly refer to outside academia relations of the teacher, they mostly refer to one-to-one relations with professionals (e.g. for practical knowledge updates or arranging students' work placements) and/or to being informed about societal and expertise-related developments. The teacher requirements do not address multiple relations, e.g. networking competence, and/or external collaboration of teachers as occurring in university-society learning settings. Existing profiles apparently are created from an inside academia-oriented perspective and do not intend to cover university-society-oriented requirements (Gilis et al. 2008; Tigelaar et al. 2004). This confirms the added value of the RLE teacher profile because it explicitly enlightens new roles, tasks and competencies for teacher performance in universitysociety learning settings that still lack in the existing profiles.

\section{Adding an out-of-school perspective to existing teacher profiles}

To start the required scholarly debate on what university-society elements to add to traditional teacher profiles, we suggest to at least add the role of broker, also called boundary crosser or bridge builder. Although the role of broker did not emerge as such from our data, we argue the broker to encompass the new RLE roles. The broker fully reflects the RLE teacher in participating in various practices simultaneously and providing connections between different practices, both within their universities as well as at the interface of university and society (Akkerman and Bakker 2011; Brandt et al. 2013; Fortuin and Bush 2010; Wenger 2000). Connecting practices has been indicated, both in our study as in cited previous studies, to be most crucial for teacher performance in all kinds of university-society collaborative settings in higher education. Brokers need to master boundary crossing competence which means that they are able to manage, switch between and integrate multiple discourses and practices across social boundaries (Akkerman and Bakker 2011; Lansu et al. 2013; Walker and Nocon 2007, Whitchurch 2009). Prominently, our identified RLE competencies appear to mainly comprise 'brokering' elements, in other words, address boundary crossing competence. The competence descriptions identified in our study are full of verbs that are typically used when referring to crossing boundaries between various practices and perspectives like connecting, exchanging, switching, adapting and aligning (Akkerman and Bakker 2011).

Another more overarching new competence element that we suggest to add to existing profiles is expressing a collaborative learning attitude, i.e. the ability and willingness to stimulate collaborative learning. Table 2 shows that this competency is linked to five of the nine RLE roles and is as such representative of an out-of-school orientation. Existing higher education profiles limit the teachers' learning capabilities to the teachers' own personal and domain-specific development (Tigelaar et al. 2004), while university-society collaborative activities are likely to strongly benefit from an attitude towards stimulating everyone's learning (e.g. Wals et al. 2009). 


\section{Limitations of the study}

Of course, the RLE profile is based on just one exemplary university-society learning setting and is created on the basis of a document analysis. This may have limited or overemphasized some roles, tasks and/or competencies. However, we complemented the document-based draft profile with interview and focus group data, which did not largely change the draft profile. The resulting profile is considered to be empirical and reflecting the worker's meaningful experience of work (McLagan 1980). Moreover, the profile was corroborated by indications on society-engaged teacher responsibilities in other university-society learning settings in which much overlap was found with the developed RLE profile.

Next, the selection of existing generic teacher profiles that we reviewed on universitysociety requirements for teacher performance was limited. We only included Dutch policy profiles in our review, and the selection of existing higher education teacher profiles was not based on a fully systematic literature review. However, the fact that at least two generic policy profiles (Onderwijscoöperatie 2014; VSNU-NOA 2016) from a country in which there is much policy pressure on providing society relevant education (Foorthuis et al. 2012) and four generic scientific profiles (Wesselink 2010; Gilis et al. 2008; Smith and Simpson 1995; Tigelaar et al. 2004) do all hardly address university-society aspects is regarded to be enough reason for recommending a debate on adding the university-society perspective to existing profiles.

In view of these considerations, we suggest this RLE teacher profile to be at least a useful source for further studies, for practical use in comparable university-society learning environments and for feeding the debate on actualising existing higher education teacher profiles in order to make these university-society proofs (Whitmer et al. 2010).

\section{Practical implications and further studies}

The RLE profile can be used as a starting reference for higher education institutions involved in any kind of university-society learning environment to investigate and reflect on teacher profile elements that might be of importance in their contexts. Institutions could first apply the profile to their own context and check to what extent the profile is applicable or should be adjusted to their own context. The profile can also be used to discuss role and task division in teams. In terms of teacher professionalisation, the profile supports the identification of competencies to be developed amongst staff and could inform the design of professionalisation trajectories. We for example designed a card game called 'Wanted: Brokers!' based on the identified roles, tasks and competencies (NRO 2019). The game supports awareness raising on brokering tasks and competencies, and peer exchange on related competence performance. As such, the RLE profile offers ample opportunities for required professional development of individual teachers and teacher teams.

Further studies that are worthwhile are validating studies, e.g. those focusing on comparisons of the exemplary RLE profile with to be created teacher profiles for other universitysociety settings. Finding similarities would strengthen our argument to structurally add some university-society elements to generic higher education teacher profiles. Additionally, further research should elaborate the brokering competencies into performance levels of teacher behaviour that represent mastering the brokering competencies to a lesser or higher degree. The boundary crossing rubric for operationalising students' brokering performance (Gulikers 
and Oonk 2019) could serve as a starting point for examining teacher performance of brokering competencies.

Moreover, professional development activities that purposefully aim at stimulating the development of these brokering competencies could be researched on their effectiveness and serve as further validations of the profile: do the identified roles, tasks and competencies indeed help teachers and teacher teams to improve their performance in university-society collaborative learning settings? How do professionalisation activities optimally contribute to teacher development, and what are the effects of professionalisation on both teacher, student and maybe even on external stakeholder performance and learning outcomes?

\section{Conclusion}

This study provides a first full university-society-oriented higher education teacher profile, and suggestions for university-society-oriented additions to existing higher education teacher profiles. The study feeds required scholarly debates on both university-society collaborative elements in future higher education teacher profiles, as well as on teacher professional development in the context of university-society collaborative learning settings. Teachers as brokers, who master boundary crossing competence and stimulate a collaborative learning attitude, are expected to serve higher education institutes' crucial engagement with society.

Open Access This article is licensed under a Creative Commons Attribution 4.0 International License, which permits use, sharing, adaptation, distribution and reproduction in any medium or format, as long as you give appropriate credit to the original author(s) and the source, provide a link to the Creative Commons licence, and indicate if changes were made. The images or other third party material in this article are included in the article's Creative Commons licence, unless indicated otherwise in a credit line to the material. If material is not included in the article's Creative Commons licence and your intended use is not permitted by statutory regulation or exceeds the permitted use, you will need to obtain permission directly from the copyright holder. To view a copy of this licence, visit http://creativecommons.org/licenses/by/4.0/.

\section{References}

Akkerman, S. F., \& Bakker, A. (2011). Boundary crossing and boundary objects. Review of Educational Research, 81(2), 132-169.

Barnett, R., \& Guzmán-Valenzuela, C. (2017). Sighting horizons of teaching in higher education. Higher Education, 73(1), 113-126.

Brandt, C. B., Cennamo, K., Douglas, S., Vernon, M., McGrath, M., \& Reimer, Y. (2013). A theoretical framework for the studio as a learning environment. International Journal of Technology and Design Education, 23(2), 329-348.

Brown, J., \& Isaacs, D. (2005). The World Café: Shaping our futures through conversations that matter. Mill Valley: World Café Community Foundation.

Brundiers, K., \& Wiek, A. (2011). Educating students in real-world sustainability research: Vision and implementation. Innovative Higher Education, 36(2), 107-124.

Brundiers, K., Wiek, A., \& Kay, B. (2013). The role of transacademic interface managers in transformational sustainability research and education. Sustainability, 5(11), 4614-4636.

Coates, H., \& Goedegebuure, L. (2012). Recasting the academic workforce: Why the attractiveness of the academic profession needs to be increased and eight possible strategies for how to go about this from an Australian perspective. Higher Education, 64(6), 875-889.

De Kock, A., Sleegers, P., \& Voeten, M. J. (2004). New learning and the classification of learning environments in secondary education. Review of Educational Research, 74(2), 141-170. 
Dubois, D. D. (1993). Competency-based performance improvement: A strategy for organisational change. Amherst: Human Resource Development Press.

European Union (High Level Group on the Modernisation of Higher Education). (2013). Report to the European Commission on improving the quality of teaching and learning in Europe's higher education institutions. Luxembourg: Publications Office of the European Union. https://doi.org/10.2766/42468.

Foorthuis, W.R., Lutz, S. \& Rippen, L. (2012). Knowledge arrangement for the learning region: Kenniswerkplaats [knowledge workplace] as a method for regional learning and lifelong learning. The Hague, the Netherlands: Ministry of Economic Affairs.

Forsyth, A., Lu, H., \& McGirr, P. (1999). Inside the service learning studio in urban design. Landscape Journal, 18(2), 166-178.

Fortuin, K. P. J., \& Bush, S. H. (2010). Educating students to cross boundaries between disciplines and cultures and between theory and practice. International Journal of Sustainability in Higher Education, 11(1), 19-35.

Giles Jr., D. E., \& Eyler, J. (1994). The theoretical roots of service-learning in John Dewey: Toward a theory of service-learning. Michigan Journal of Community Service Learning, 1(1), 77-85.

Gilis, A., Clement, M., Laga, L., \& Pauwel, P. (2008). Establishing a competence profile for the role of studentcentred teachers in higher education in Belgium. Research in Higher Education, 49, 531-554.

Gulikers, J., \& Oonk, C. (2019). Towards a rubric for stimulating and evaluating sustainable learning. Sustainability, 11(4), 969.

Guzmán-Valenzuela, C. (2015). Unfolding the meaning of public(s) in universities: Toward the transformative university. Higher Education, 2015, 1-13.

Herrington, J., \& Oliver, R. (2000). An instructional design framework for authentic learning environments. Educational Technology Research and Development, 48(3), 23-48.

Jacoby, B. (2014). Service-learning essentials: Questions, answers, and lessons learned. San Francisco: Jossey-Bass.

Jongbloed, B., Enders, J., \& Salerno, C. (2008). Higher education and its communities: Interconnections, interdependencies and a research agenda. Higher Education, 56(3), 303-324.

Klein, P., Munazza, F., McEwen, L., Moser, S. C., Schmidt, D., \& Zupan, S. (2011). Dismantling the ivory tower: Engaging geographers in university-community partnerships. Journal of Geography in Higher Education, 35(3), 425-444.

Kyvik, S. (2013). The academic researcher role: Enhancing expectations and improved performance. Higher Education, 65(4), 525-538.

Landis, J. R., \& Koch, G. G. (1977). The measurement of observer agreement for categorical data. Biometrics, $159-174$

Lang, D. J., Wiek, A., Bergmann, M., Stauffacher, M., Martens, P., Moll, P., Swilling, M., \& Thomas, C. J. (2012). Transdisciplinary research in sustainability science: Practice, principles, and challenges. Sustainability Science, 7(1), 25-43.

Lansu, A., Boon, J., Sloep, P. B., \& Van Dam-Mieras, R. (2013). Changing professional demands in sustainable regional development: A curriculum design process to meet transboundary competence. Journal of Cleaner Production, 49, 123-133.

McLagan, P. (1980). Competency models. Training and Development Journal, 34(12), 22-26.

Meijles, E., \& Van Hoven, B. (2010). Using the rural atelier as an educational method in landscape studies. Journal of Geography in Higher Education, 34(4), 541-560.

Miles, M. B., Huberman, A. M., \& Saldana, J. (2014). Qualitative data analysis: A methods sourcebook. SAGE Publications, Incorporated.

Mulder, M. (2014). Conceptions of professional competence. In S. Billet, C. Harteis, \& H. Gruber (Eds.), International handbook of research in professional and practice-based learning (pp. 107-137). Dordrecht: Springer.

Mulder, M. (Ed.). (2017). Competence-based vocational and professional education: Bridging the worlds of work and education. Cham: Springer. https://doi.org/10.1007/978-3-319-41713-4.

Mulder, M., Wesselink, R., \& Bruijstens, H. C. J. (2005). Job profile research for the purchasing profession. International Journal of Training and Development, 9(3), 185-204.

Nationaal Regieorgaan Onderwijsonderzoek [NRO; National Initiative for Education Research]. (2019). Wanted: Brokers! Discover tasks, competencies and personal qualities of the broker. Wageningen: Wageningen University and Research, Education and Learning Sciences.

OECD-IMHE. (2012). Fostering quality teaching in higher education: Policies and practices. An IMHE Guide for Higher Education Institutions. Paris: OECD-IMHE. Retrieved from www.oecd.org/edu/imhe. Accessed 1 Nov 2018.

Onderwijscoöperatie. (2014). Voorstel Bekwaamheidseisen [proposal capability requirements]. Utrecht: Onderwijscoöperatie Retrieved from http://archief.onderwijscooperatie.nl/. Accessed Apr 2014. 
Oonk, C., Gulikers, J., \& Mulder, M. (2016). Educating collaborative planners: Strengthening evidence for the learning potential of multi-stakeholder regional learning environments. Planning Practice \& Research, 31(5), 533-551.

Oonk, C., Gulikers, J., \& Mulder, M. (2017). Educating boundary crossing planners: Evidence for student learning in the multi-stakeholder regional learning environment. Journal of Planning Education and Research. https://doi.org/10.1177/0739456X17737598.

Peer, V., \& Stoeglehner, G. (2013). Universities as change agents for sustainability: Framing the role of knowledge transfer and generation in regional development processes. Journal of Cleaner Production, 44, 85-95.

Rosenberg Daneri, D., Trencher, G., \& Petersen, J. (2015). Students as change agents in a town-wide sustainability transformation: The Oberlin Project at Oberlin College. Current Opinion in Environmental Sustainability, 16, 14-21.

Ruskovaara, E., Pihkala, T., Seikkula-Leino, J., \& Riikka Järvinen, M. (2015). Broadening the resource base for entrepreneurship education through teachers' networking activities. Teaching and Teacher Education, $4,62-70$.

Scholz, R. W., \& Steiner, G. (2015). The real type and ideal type of transdisciplinary processes: Part I-theoretical foundations. Sustainability Science, 10(4), 527-544.

Sletto, B. (2010). Educating reflective practitioners: Learning to embrace the unexpected through service learning. Journal of Planning Education and Research, 29(4), 403-415.

Smith, K. S., \& Simpson, R. D. (1995). Validating teaching competencies for faculty members in higher education: A national study using the Delphi method. Innovative Higher Education, 19(3), 223-234.

Stauffacher, M., Walter, A. I., Lang, D. J., Wiek, A., \& Scholz, R. W. (2006). Learning to research environmental problems from a functional socio-cultural constructivism perspective: The transdisciplinary case study approach. International Journal of Sustainability in Higher Education, 7(3), 252-275.

Strauss, A. L. (1987). Qualitative analysis for social scientists. Cambridge: Cambridge University Press.

Tigelaar, D. E. H., Dolmans, D., Wolfhagen, I., \& Van Der Vleuten, C. (2004). The development and validation of a framework for teaching competencies in higher education. Higher Education, 48, 253-268.

Trencher, G. P., Yarime, M., \& Kharrazi, A. (2013). Co-creating sustainability: Cross-sector university collaborations for driving sustainable urban transformations. Journal of Cleaner Production, 50, 40-55.

Vilsmaier, U., \& Lang, D. J. (2015). Making a difference by marking the difference: Constituting in-between spaces for sustainability learning. Current Opinion in Environmental Sustainability, 16, 51-55.

VSNU-NOA. (2016). Competentie-Instrument voor de Nederlandse Universiteiten 2010: Versie 2016. [Competence Instrument for the Dutch Universities 2010: version 2016]. The Hague, the Netherlands: VSNU.

Walker, D., \& Nocon, H. (2007). Boundary-crossing competence: Theoretical considerations and educational design. Mind, Culture, and Activity, 14(3), 178-195.

Wals, A. E. J., Van Der Hoeven, N., \& Blanken, H. (2009). The acoustics of social learning: Designing learning processes that contribute to a more sustainable world. Wageningen: Wageningen Academic Publishers.

Watson, D., Hollister, R., Stroud, S. E., \& Babcock, E. (2011). The engaged university: International perspectives on civic engagement. Taylor \& Francis.

Webb, T., \& Burgin, S. (2009). Engaged service learning: Implications for higher education. Journal of Learning Design, 3(1), 41-56.

Wenger, E. (2000). Communities of practice and social learning systems. Organization, 7(2), 225-246.

Wesselink, R. (2010). Comprehensive competence-based vocational education: The development and use of a curriculum analysis and improvement model. (Doctoral Dissertation). Wageningen: Wageningen University.

Whitchurch, C. (2009). The rise of the "blended professional" in higher education: A comparison between the United Kingdom, Australia and the United States. Higher Education, 58(3), 407-418.

Whitmer, A., Ogden, L., Lawton, J., Sturner, P., Groffman, P. M., Schneider, L., Hart, D., Halpern, B., Schlesinger, W., Raciti, S., Bettez, N., Ortega, S., Rustad, L., Pickett, S., \& Killilea, M. (2010). The engaged university: Providing a platform for research that transforms society. Frontiers in Ecology and the Environment, 8(6), 314-321.

Yarime, M., Trencher, G., Mino, T., Scholz, R. W., Olsson, L., Ness, B., Frantzeskaki, N., \& Rotmans, J. (2012). Establishing sustainability science in higher education institutions: Towards an integration of academic development, institutionalization, and stakeholder collaborations. Sustainability Science, 7(1), 101-113.

Publisher's note Springer Nature remains neutral with regard to jurisdictional claims in published maps and institutional affiliations. 


\section{Affiliations}

Carla Oonk $^{1}$ • Judith T. M. Gulikers ${ }^{2}$ - Perry J. den Brok ${ }^{2} \cdot$ Renate Wesselink $^{2}$ • Pieter-Jelle Beers ${ }^{3} \cdot$ Martin Mulder $^{2}$

Carla Oonk

carla.oonk@wur.nl

1 Education and Learning Sciences, Wageningen University and Research, P.O. Box 8130, 6700 EW Wageningen, The Netherlands

2 Education and Learning Sciences, Wageningen University and Research, Wageningen, The Netherlands

3 The Dutch Research Institute For Transitions, Erasmus University Rotterdam, Rotterdam, The Netherlands 